\title{
Determination of shareholders' welfare with financing quality as a moderating variable
}

\author{
Tengku Chandra Husnadi ${ }^{1}$, Tatik Marianti ${ }^{2}$, Tarisya Ramadhan ${ }^{3}$ \\ 1,2IEF Trisakti University \\ ${ }^{3}$ University of Raharja \\ 1,2 Jl. Kyai Tapa No.1, Grogol, Jakarta Barat \\ $3 \mathrm{Jl}$. Jenderal Sudirman No.40, Cikokol, Tangerang \\ e-mail: tchandra h@yahoo.com ${ }^{1}$, tatik m2002@yahoo.com ${ }^{2}$, tarisya@raharja.info ${ }^{3}$
}

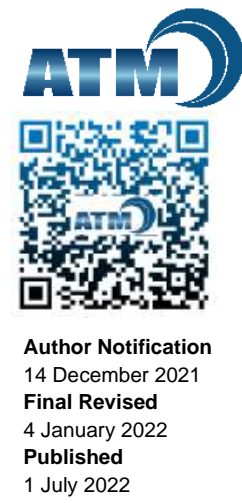

To cite this document :

Husnadi, T.C., Marianti, T., \& Ramadhan, T.(2022). Determination of shareholders' welfare with financing quality as a moderating variable. Aptisi Transactions on Management (ATM), 6(2), 191-208.

DOI :

https://doi.org/10.33050/atm.v6i2.1799

\begin{abstract}
The purpose of this study was to analyze the factors that might affect the shareholder welfare ratio (ROE). These factors include independent variables consisting of financing distribution ratio (FDR), low-cost funds ratio (CASA), net operating margin ratio (NOM), expensebased income ratio (FIR), and Financing Quality ratio (NPF). Furthermore, to determine the relationship of Islamic bank performance indicators on shareholder welfare with the ROE ratio indicator, NPF is a moderate variable. The method used to analyze the holder's welfare ratio (ROE) is moderate regression analysis with the error error model (ECM). The research sample used is the entire research population, namely monthly data from the Islamic banking industry for the period 2012-2020 (consisting of 14 Islamic commercial banks and 20 Islamic business units). The results of this study note that in the long run: FDR has a positive and significant effect on the ROE ratio, the NOM ratio has a negative and significant effect on the ROE ratio. While the variables of CASA ratio, FIR ratio and NPF have no effect on the ROE ratio. Furthermore, the NPF Moderating Variable strengthens the relationship of all direct and significant variables with the Shareholder Welfare Ratio (ROE), namely NPF moderates the negative and significant effect of FDR on the ROE ratio, NPF moderates the positive and significant effect of the ratio. on the ROE ratio. Furthermore, other variables NPF Moderating Casa and FIR have no effect on the $R O E$ ratio. For the short term: FIR has a positive and significant effect on the ROE ratio, the NOM ratio has a negative and significant effect on the ROE ratio. While the FDR ratio, CASA ratio and NPF ratio variables have no effect on the ROE ratio. Furthermore, the NPF variable strengthens the relationship of all variables directly and significantly to the Shareholder Welfare Ratio (ROE), namely NPF moderates the negative and significant effect of FIR on the roe ratio, NPF moderates the positive and significant effect of the ratio. on the ROE ratio. While other variables, moderate NPF, FDR and CASA, have no effect on the ROE ratio. The implication of this study is to measure the welfare of shareholders, in this case the performance of Islamic banks with the ROE ratio approach. Why is the welfare ratio of all shareholders (ROE) important, because in accordance with the existence of Islamic banks it aims to provide benefits (maslahah) for the ummah. Islamic banks in carrying out their mandate have a commitment to be able to provide expectations from shareholders in the company and be able to develop products that are in accordance with the wishes and needs of customers. So from this study it can be said that of the 5 variables that affect the price. financing distribution ratio (FDR), low cost funds ratio (CASA), net operating margin ratio (NOM), cost-based income ratio (FIR) and Financing Quality ratio (NPF).
\end{abstract}

Keywords: Islamic banks, shareholder welfare ratio (ROE), Financing to Deposit Ratio (FDR), Low-cost funds ratio (CASA), Net Operating Margin Ratio (NOM), Fee Based Income Ratio (FIR) and Non-Performing Financing Ratio (NPF). 


\section{Introduction}

Return On Equity (ROE) It is the ratio of net profit after tax to equity (average core capital) which is used to measure the company's ability to provide benefits to shareholders. The ROE standard to PBI No.6/10/PBI/2004 is 5\%-12.5\% [1]. The greater the ROE, the greater the level of profit obtained by the bank which has an impact on increasing the bank's position in terms of capital management [2]. The higher the return, the better because it means that the dividends distributed or reinvested as retained earnings are also getting bigger. Profitability Ratio Return on Equity (ROE) is a ratio that describes the company's ability to generate profits by using the capital embedded in it [3]. This ratio measures the company's ability to obtain profits available to the company's shareholders. For investors, the ROE metric is the easiest to find out how high a company's potential is to generate profits. With the return on equity, investors can draw conclusions about the profitability of shares easily and quickly. The components of capital (including core capital) to Indonesian banking statistics issued by the OJK consist of: paid-in capital, reserves, last year's profit and loss, current year's profit and loss after tax, additional paidin capital and financing capital [4]. The formula used to Rianto:

\section{ROE $=$ Net Profit After Tax Total Equity/Average Core Capital}

the Return on Equity (ROE) ratio is a good starting point in the analysis of a bank's financial condition for the following reasons:

a. If the ROE is relatively low compared to other banks, it will tend to reduce the bank's access to new capital that may be needed to expand and maintain a competitive position in the market;

b. Low ROE can limit bank growth because regulations require assets (at maximum value) to be a certain amount of equity capital;

c. ROE can be divided into sections that help to identify trends in bank performance.

The banking performance indicator in disbursing funds collected in the form of financing is the financing deposit to ratio (FDR) [5]. This ratio shows the bank's ability to channel financing from third party funds or funds from the public that have been collected by the bank. The higher the FDR ratio, the better the intermediation function of the Islamic bank. With a good Islamic bank function in disbursing funds in the community, it will have an impact on the distribution of good profit sharing from Islamic banks which will also increase the Return on Equity of Islamic banks. However, there is a maximum limit to be developed in order to maintain bank liquidity, in accordance with the provisions issued by the regulator (Bank Indonesia/BI), namely Bank Indonesia Regulation No. 17/11/PBI/2015 dated June 25. 2015, the maximum FDR limit was $100 \%$ and the minimum FDR limit was 78\% [6]. Limiting the maximum FDR so that banks have sufficient liquidity reserves as a result of the funds being channeled to provide financing to the public. Thus, if there is a massive withdrawal of funds by the public, the bank will be able to fulfill it. Intermediation is a banking function in a country's financial system, namely regulating the amount of money circulating in the community, while the money supply in banks is indicated by the Loan to Deposit Ratio (LDR) in conventional banking, while in Islamic banks it is Financing for Deposits (FDR) [7]. the Financing to Deposit Ratio (FDR) can be formulated as follows:

$$
F D R=\frac{\text { Total Financing }}{\text { Total Third Party Funds }}
$$

The high or low FDR ratio indicates the level of liquidity of the bank. So that the higher the FDR number of a bank, it means that it is described as a less liquid bank compared to a bank that has a smaller ratio. On the other hand, the lower the FDR indicates the bank's lack of effectiveness in disbursing financing. If a bank's FDR ratio is at the standard set by Bank Indonesia, the profit earned by the bank will increase (assuming the bank is able to channel financing effectively) [8]. With the increase in profit, the Return on Equity (ROE) will also increase, because profit is a component that makes up Return on Equity (ROE). 
One of the banking efforts to increase profitability is a low-cost fundraising strategy or commonly known as a Current Account Saving Account (CASA). CASA is a low-cost fund sourced from current accounts and savings [9]. These two types of third-party funds are referred to as lowcost funds because to obtain both, the bank does not need to spend a lot of money. The interest/margin that must be issued by the bank as a cost to obtain funds from demand deposits and savings is not as much as the interest/margin that must be issued by the bank as a cost to obtain funds from deposits. Therefore, the use of CASA is expected to increase banking cost efficiency [10]. Cost efficiency describes the difference between input costs and the best practices that an entity can take with regard to these costs. Low-cost funds from CASA are expected to reduce the cost of funds so as to encourage cost efficiency in bank activities to earn profits. This makes CASA the target of all banks to increase their profitability [11]. CASA is one of the aspects that can affect the level of profitability of banks, so that it will affect the ratio of bank profitability, especially Return on Equity. The CASA ratio shows the proportion of low-cost funds compared to the total third party funds obtained by banks. The higher the CASA, the lower the cost of funds that must be spent by banks, this will increase the efficiency of banking operations. Finally, CASA is one of the banking strategies to increase bank profitability. Banks always try to increase the proportion of CASA from year to year. CASA, which is a low-cost fund, can improve banking efficiency [12]. The higher the low-cost funds owned by the bank, the higher the efficiency of the bank, so that its profitability will increase [13].

In addition to low-cost funds as an effort to increase profitability, the management of productive assets by management is also an important factor in determining the strategy to increase company profits [14]. Net Operating Margin (NOM) is a ratio used to measure the ability of bank management in managing earning assets to generate revenue sharing on earning assets managed by banks, so that financial performance is increasing. The higher the Net Operating Margin (NOM) of a bank, the higher the Return on Assets and Return on Equity.

Net Operating Margin (NOM) is the ratio between profit-sharing income (bank operating income earned) minus profit-sharing costs (bank operating costs that become expenses) divided by the average earning assets income (average earning assets used) [15]. This ratio describes the level of total net operating income obtained by using the productive assets owned by the bank. The greater this ratio, the higher the operating income obtained from productive assets managed by the bank so that the possibility of the bank being in a problematic condition is getting smaller [16]. Net Operating Margin itself aims to evaluate the bank in managing various risks that may occur in margin and profit sharing. This means that when the margin or profit sharing changes, the income and costs of the margin or profit sharing will also change. Net Operating Margin itself is a ratio that is closely related to the ability of banks to manage their productive assets so that they can generate a margin or net profit sharing. The formulas commonly used in calculating the soundness level of Islamic banks are as follows:

\section{$\mathrm{NOM}=$ Net Operating Income $\times 100 \%$ Average Earning Assets}

The income obtained from the bank does not only come from collecting public funds and then channeling it to debtors in the form of credit/financing [17]. Although almost $70 \%$ of bank profitability is derived from profit-sharing-based credit/financing, banks need to set another strategy, namely optimizing income from bank services, which is commonly called fee-based income. This fee-based income has almost no risk, such as income from financing, because there is a potential for debtors to experience default (non-performing financing). Income from fee-based income is the most calculated source of income in the banking business today. Banks must improve their human resource management capabilities supported by distribution networks and sophisticated technology in order to provide good service to customers so that banks are able to increase fee-based income [18].

The importance of fee-based income for Islamic banks is reflected in articles 3 and 4 of Bank Indonesia regulation Number: 9/1PBI/2007 concerning the rating system for soundness of commercial banks based on sharia principles, where income diversification, including the ability of banks to earn fee-based income, is a contributing factor [19]. assessed in the assessment of the soundness of Islamic commercial banks. Another factor that makes fee-based income even more important is that currently and in the future, bank competition is getting tougher between 
sharia and conventional banks, with this intense competition the margin between cost of funds and income from financing (lending) will be getting thinner. then fee-based income will play a greater role [20].

The quality of lending or financing is one of the important financial indicators in maintaining a bank's reputation. Thus, to maintain reputation and profitability (ROE) banks try to maintain the quality of financing so that the assets owned by the bank can generate optimal profits. Furthermore, based on previous studies), financing quality has a negative and significant effect on ROE. to IAI in SAK Non-Performing Financing/non-performing financing are: and or interest/profit sharing has passed 90 days or more after maturity Non-Performing Financing (NPF) is an indicator of the health of a bank's asset quality in managing financing distribution Asset quality assessment is an assessment of the condition of the Bank's assets and the adequacy of risk management to Bank Indonesia Regulation Number 6/10/PBI/2004 dated 12 April 2004 concerning the $\mathrm{K}$ Level assessment system soundness of Commercial Banks and Islamic Banks, the higher the NPF value (above 5\%), the bank is not healthy [21]. This level of Non-Performing Financing (NPF) will automatically affect profitability, the higher the NPF, the lower the profitability and vice versa, if the NPF is lower, the profitability will be higher, as stated, if non-performing financing is very bad [22]. large and the reserves formed are also large resulting in the bank's capital being likely to be negative so that the profits obtained will be disrupted. The level of nonperforming financing risk can be formulated:

\section{Non-Performing Financing $=\underline{\text { Troubled Financing }}$ Total Financing}

In accordance with the phenomena mentioned above, research is needed that analyzes the variables that can affect the welfare of shareholders which include the ability to distribute Islamic bank financing (FDR), low-cost funds (CASA ratio), Islamic bank productivity (NOM ratio), fee -based income (FIR) and quality of financing (NPF) [23]. Furthermore, because currently one of the indicators used by regulators in determining the profitability of performance is ROE, the quality of financing (NPF) in this research is a moderating variable. The research that will be conducted is research that aims to determine the factors that affect the welfare of shareholders from a sharia perspective which is moderated by the current performance measurement, namely ROE. Thus, the title of this dissertation is "Determinants of Shareholder Welfare with Financing Quality as Moderating Variable [24].

\section{Research Method}

The research method used in this study refers to the Tawhid String Relationship (TSR) which is sourced from the Qur'an and Hadith as the basis. In practice, the goal of Islamic banks in addition to profit, there are also spiritual and social aspects whose ultimate goal is the achievement of benefit for all people. This is an implication of the implementation of TSR, so that the application of TSR can be implemented in Islamic banks.

The implementation of TSR in the performance of Islamic banks is realized by the achievement of welfare both from the shareholder side (shareholders), in this case those who provide capital deposits to Islamic banks, as well as welfare for all stakeholders [25]. This is what distinguishes Islamic banks and conventional banks, although the measurement indicators used are the same, namely the Return on Equity ratio. However, if we relate it to the objectives of maqashid sharia which in business practice must be based on fairness, balance and benefit, welfare will be achieved. Thus, it is necessary to analyze whether the application of ROE in Islamic banks can achieve shareholder welfare [26].

The main objective of this study is to analyze and explain the performance of Islamic banks on the welfare of shareholders based on the principles of CSR. In addition, endogenous or internal factors that influence the business activities of Islamic banks in this dissertation include the ability of Islamic banks to channel financing (FDR), low-cost fundraising (CASA), ability to manage productive assets (NOM), increase fee-based income ( FIR) and quality of financing (NPF) [27]. 
The implementation of the TSR method in this study can be described in figure 2.1 below:

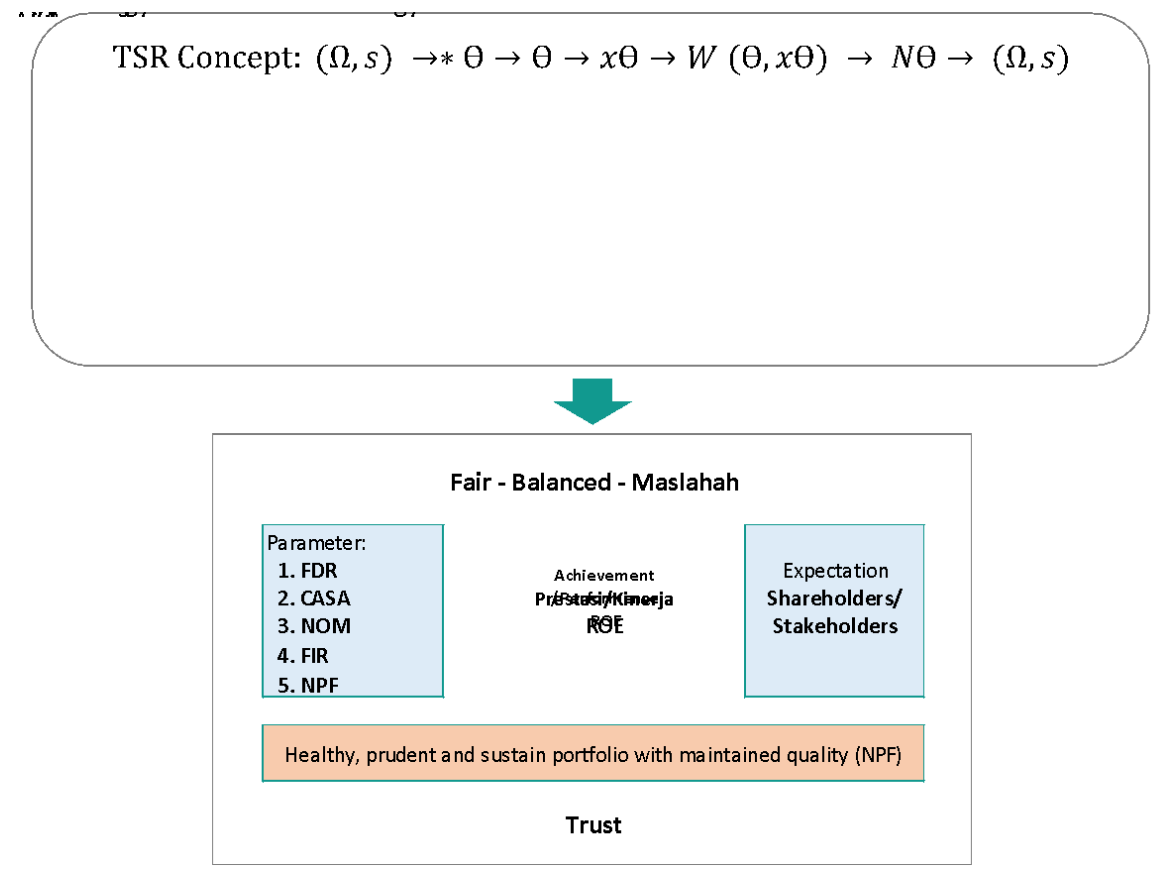

Figure 2.1 Application of the CSR Concept in the Research Model

Furthermore, to implement sharia values in financial institutions such as Islamic banks, adequate knowledge is needed which is not only religious knowledge, but also knowledge about risk, finance, economics and so on. Islamic banks as banks that have different goals from conventional banks should have different values from conventional banks. The indicator that can be used to measure the performance of Islamic banks is ROE. This ROE includes the bank's ability to fulfill aspects of justice, social aspects and welfare aspects in accordance with the TSR concept [28].

\subsection{Variables and Measurements}

A variable is a trait that has a variety of values or what is also called a variation that is very closely related to value. Variables are used for all branches of science to find a systematic relationship between variables. The dependent variable or the dependent variable is the main variable to be investigated in a study. The dependent variable is a variable that is influenced by other variables, namely the independent variable/independent variable, while the independent variable or independent variable is a number of variables that affect the main variable, namely the dependent variable. In this study there are five independent variables, namely Financing to Deposit Ratio (FDR), Current Account Saving Account (CASA), Net Operating Margin (NOM), Fee-Based Income Ratio (FIR) and financing quality (NPF) which affect the dependent variablewhich is Return on Equity (ROE). This study also includes a moderating variable to strengthen the influence of the independent variable on the dependent variable, namely using NonPerforming Financing (NPF) [29].

The use of Return on Equity in measuring the performance of Islamic banks is carried out to test whether Islamic banks have provided benefits and welfare for stakeholders, in this case shareholders (as shareholders). The ROE ratio is one of the methods used in evaluating the performance of Islamic banks against the expectations of shareholders that the principles of justice, lawfulness and welfare are achieved. In contrast to previous studies, in this study there are six ratios used in this study, namely the Shareholder Welfare Ratio (Return on Equity), the ratio of financing distribution to third party funds (FDR), the ratio of low-cost funds (CASA), the ratio of productive asset management (NOM), fee-based income ratio (FIR) and financing quality ratio (NPF) [30]. 
Tabel 2.1 Operasional Variabel

\begin{tabular}{|c|c|c|c|}
\hline Variabel & Pengukuran & Skala & Sumber \\
\hline $\begin{array}{l}\text { Return On Equity } \\
\text { (ROE) }\end{array}$ & $\frac{\text { Laba Bersih Setelah Pajak }}{\text { Total Ekuitas }}$ & Rasio & $\begin{array}{l}\text { (Idrus, Ali, 2018; Anggraeny, } \\
\text { Anelia, 2020; Aulia, } \\
\text { Farrashita, and Prasetiono } \\
\text { Prasetiono, 2015) }\end{array}$ \\
\hline $\begin{array}{c}\text { Financing to } \\
\text { Depsit Ratio (FDR) }\end{array}$ & $\frac{\text { Total Pembiayaan }}{\text { Total Dana Pihak Ketiga }}$ & Rasio & $\begin{array}{l}\text { (Irhamsyah, Anwar, 2010; } \\
\text { Anggraeny, Anelia, 2020; } \\
\text { Aulia, Farrashita, and } \\
\text { Prasetiono Prasetiono, 2015) }\end{array}$ \\
\hline $\begin{array}{l}\text { Carrent Account } \\
\text { Saving Account } \\
\text { (CASA) }\end{array}$ & $\begin{array}{c}\text { Giro + Tabungan } \\
\text { Total Dana Pihak Ketiga }\end{array}$ & Rasio & $\begin{array}{l}\text { (Khairunisa, Jihan, Muslim } \\
\text { Marpaung, and Anriza Witi } \\
\text { Nasution, 2020; Khabibah, } \\
\text { Nibras Anny, Sully Kemala } \\
\text { Octisari, and Agustina Prativi } \\
\text { Nugraheni, 2020) } \\
\end{array}$ \\
\hline $\begin{array}{l}\text { Net Operating } \\
\text { Margin (NOM) }\end{array}$ & $\frac{\text { (Pend.Ops-Biaya Bagi Hasill)-Beban Ops. }}{\text { Rata-rata Aktiva Produktif }}$ & Rasio & $\begin{array}{l}\text { (Laely, Dyah Nurul, 2020; } \\
\text { Rifai, F., \& Suyono, N. A, } \\
\text { 2019; Yusuf, M, 2017) }\end{array}$ \\
\hline $\begin{array}{l}\text { Fee Based Income } \\
\text { Ratio (FIR) }\end{array}$ & $\frac{\text { Pendapatan Fee Based Income }}{\text { Total Pendapatan Operasional }}$ & Rasio & $\begin{array}{c}\text { (Kiki, Aristia, 2021; Laely, } \\
\text { Dyah Nurul, 2020; Cahyo, G. } \\
\text { N., 2018) }\end{array}$ \\
\hline $\begin{array}{l}\text { Non Performing } \\
\text { Financing (NPF) }\end{array}$ & $\frac{\text { Kolektibilitas Pembiayaan } 3,4 \text { dan } 5}{\text { Total Pembiayaan }}$ & Rasio & $\begin{array}{l}\text { (Anggraeny, Anelia, 2020; } \\
\text { Aulia, Farrashita, and } \\
\text { Prasetiono Prasetiono, 2015; } \\
\text { Rifai, F., \& Suyono, N. A, } \\
\text { 2019) }\end{array}$ \\
\hline
\end{tabular}

\subsection{Methods and Samples}

The analytical method used in this research is Error Correction Model (ECM) analysis with long-term and short-term models because the observations used in this study consist of Islamic banking industry data. The sample is part of the population to be studied. Sampling was done because of the limitations of researchers in conducting research to take a very large population. The samples taken are Islamic Banking Statistics (SPS) and Indonesian Banking Statistics (SPI) data contained in the Financial Services Authority (OJK), the number of Sharia Commercial Banks (BUS) as of December 2020 is 14 Sharia Commercial Banks and 20 Sharia Business Units (period 2012-2020).

\subsection{Framework and Hypotheses}

Based on theoretical studies and previous research, the research framework can be shown in Figure 2.2 below: 


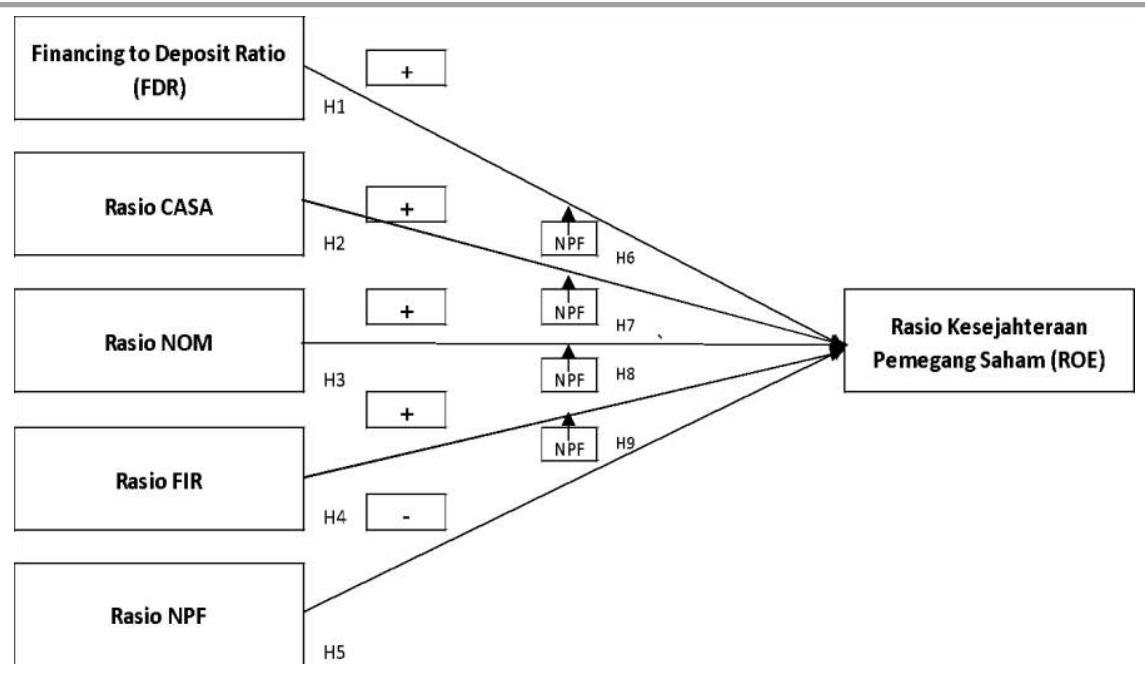

Figure 2.2 Conceptual Framework for Research on Determinants of NPF Factors as Moderating Variables

Referring to Figure 2.2 above, the hypothesis in this study can be formulated as follows:

1. Hypothesis 1: FDR has a positive effect on the Shareholder Welfare Ratio;

2. Hypothesis 2: The CASA ratio has a positive effect on the Shareholder Welfare Ratio;

3. Hypothesis 3: NOM ratio has a positive effect on Shareholder Welfare Ratio;

4. Hypothesis 4: FIR ratio has a positive effect on Shareholder Welfare Ratio;

5. Hypothesis 5: The NPF Ratio has a negative effect on the Shareholder Welfare Ratio;

6. Hypothesis 6: Moderation NPF Ratio has a positive effect on FDR on the Shareholder Welfare Ratio;

7. Hypothesis 7: Moderation NPF Ratio has a positive effect on the CASA Ratio on the Shareholder Welfare Ratio;

8. Hypothesis 8: Moderation NPF Ratio has a positive effect on the NOM Ratio on the Shareholder Welfare Ratio;

9. Hypothesis 9: Moderation NPF Ratio has a positive effect on the FIR Ratio on the Shareholder Welfare Ratio.

\section{Result and Discussion}

3.1 Research Result

\subsubsection{Stationarity Test}

Table 3.1 Augmented Dickey-Fulley Stationarity Test Results

\begin{tabular}{|c|c|c|}
\multirow{2}{*}{ Variabel } & $\begin{array}{c}\text { Table 3.1 Augmented Dickey-Fulley Stationarity Test Results } \\
\text { Level }\end{array}$ & $\begin{array}{c}\mathbf{1}^{\text {st }} \text { Difference } \\
\end{array}$ \\
\cline { 2 - 3 } Prob. Augmented Dickey-Fuller & Prob. Augmented Dickey-Fuller \\
\hline CASA & 0.4443 & 0.0000 \\
\hline FDR & 0.8914 & 0.0000 \\
\hline FIR & 0.7174 & 0.0000 \\
\hline NOM & 0.1295 & 0.0000 \\
\hline NPF & 0.4014 & 0.0000 \\
\hline
\end{tabular}

Source: Eview 10 Software Processing Results

Description:

ROE : Return on Equity

CASA : Current Account Saving Account

FDR : : Financing to Deposit Ratio

FIR : Fee-Income Ratio 


\section{NOM : Net Operating Margin \\ NPF : Non-Performing Financing}

Based on the results of the ADF stationarity test in table 3.1, all variables in the study, both independent and dependent variables, are not stationary at the level with the overall prob results. ADF of each variable $>0.05(\alpha)$. Then proceed with testing again at the first difference level where the results of the test produce prob. The overall ADF is $0.0000<0.05(\alpha)$ so that all variables are stationary at the first difference level.

\subsubsection{Cointegration Test}

After doing the stationarity test, a cointegration test is needed to see if there is a longterm equilibrium relationship. The requirement for the co-integrated model is that the residuals must be stationary at the level level.

Table 3.2 Cointegration Test Results Level

\begin{tabular}{|c|c|c|c|c|c|}
\hline \multirow{2}{*}{ Uji Akar Unit } & \multirow{2}{*}{ Prob. ADF } & \multirow{2}{*}{ t-statistik } & \multicolumn{3}{|c|}{ Test critical values } \\
\cline { 4 - 6 } & & & $1 \%$ & $5 \%$ & $10 \%$ \\
\hline ECT & 0.0000 & -7.553006 & -3.492523 & -2.888669 & -2.581313 \\
\hline
\end{tabular}

Source: Eview 10 Software Processing Results

Based on the results of the cointegration test in Table 3.2, it can be concluded that the residuals are cointegrated with the results of the prob. Augmented Dickey Fuller is $0.0000<0.05$ ( $\alpha$ ) so that the short-term model or ECM can be used.

\subsubsection{Long-Term Estimation}

Table 3.3 Estimation Results of the Long-Term Model

\begin{tabular}{|c|c|c|c|c|}
\hline Variabel & Koefisien & Std. Error & t-Statistik & Prob. \\
\hline C & -113.6439 & 57.81774 & -1.965554 & 0.0522 \\
\hline FDR & 1.398482 & 0.308217 & 4.537324 & 0.0000 \\
\hline CASA & 0.649103 & 0.901218 & 0.720251 & 0.4731 \\
\hline FIR & 0.284223 & 0.396683 & 0.716499 & 0.4754 \\
\hline NOM & -13.90471 & 4.154860 & -3.346613 & 0.0012 \\
\hline NPF & 26.18989 & 16.84953 & 1.554340 & 0.1233 \\
\hline FDR ${ }^{*}$ NPF & -0.308768 & 0.091399 & -3.378259 & 0.0010 \\
\hline CASA $^{*} N P F$ & -0.141277 & 0.261479 & -0.540301 & 0.5902 \\
\hline FIR ${ }^{*}$ NPF & -0.047843 & 0.092351 & -0.518054 & 0.6056 \\
\hline NOM NPF & 4.398280 & 1.183032 & 3.717803 & 0.0003 \\
\hline Adj. R-Squared & & \multicolumn{3}{|c|}{0.798140} \\
\hline F-Statistik & & 48.00771 & \\
\hline Prob. F-Statistik & & \multicolumn{3}{|c|}{0.0000} \\
\hline
\end{tabular}




\section{Source: Eview 10 Software Processing Results}

Based on the estimation results in Table 3.3, the long-term model equation in the study can be written as follows:

$\mathrm{ROE}=-113.6439+1.398482 \mathrm{FDR}+0.649103 \mathrm{CASA}+0.284223 \mathrm{FIR}-13.90471 \mathrm{NOM}+$ 26.18989NPF - $0.308768 \mathrm{FDR}^{\star} \mathrm{NPF}-0.141277 \mathrm{CASA}^{*} \mathrm{NPF}+0.047843 \mathrm{FIR}{ }^{\star} \mathrm{NPF}+$ 4.398280NOM*NPF + e

In equation 3.1, it is found that in the long term FDR and NOM have a significant effect on ROE with a prob value. $t$-stats are each smaller $(<) 0.05$ and have positive and negative coefficients, respectively. While CASA, FIR and NPF in the long term have a positive and insignificant effect on ROE with a prob value. t-stat is each greater $(>) 0.05$. Then, CASA and FIR moderated by NPF had a negative and insignificant effect with a prob.t-stat greater $(>)$ 0.05 . However, FDR and NOM moderated by NPF have a significant effect on ROE with prob. $\mathrm{t}$-stat is $0.0000<0.05(\alpha)$ and each coefficient is negative and positive.

The ability of the independent variable in explaining the dependent variable in the longterm estimation is 0.798140 or 79 percent, the remaining 21 percent is influenced by other variables that are not included in the model or errors. The effect of independent variables on ROE together has a significant effect. This can be seen from the estimation results of prob. $\mathrm{f}$ stat of $0.0000<0.05(\alpha)$.

\subsubsection{Short-Term Estimation (Error Correction Model)}

Table 3.4 Short-term Estimation Results

\begin{tabular}{|c|c|c|c|c|}
\hline Variabel & Koefisien & Std. Error & t-Statistik & Prob. \\
\hline$C$ & 0.029420 & 0.188786 & 0.155837 & 0.8765 \\
\hline $\mathrm{D}(\mathrm{FDR})$ & 0.400103 & 0.374264 & 1.069037 & 0.2877 \\
\hline $\mathrm{D}(\mathrm{CASA})$ & 0.647968 & 0.894482 & 0.724405 & 0.4706 \\
\hline $\mathrm{D}(\mathrm{FIR})$ & 0.963511 & 0.306948 & 3.139005 & 0.0023 \\
\hline $\mathrm{D}(\mathrm{NOM})$ & -13.67546 & 2.950292 & -4.635290 & 0.0000 \\
\hline $\mathrm{D}(\mathrm{NPF})$ & 5.050030 & 15.43752 & 0.327127 & 0.7443 \\
\hline $\mathrm{D}\left(\mathrm{FDR}^{\star} \mathrm{NPF}\right)$ & -0.021727 & 0.106358 & -0.204278 & 0.8386 \\
\hline $\mathrm{D}\left(\mathrm{CASA}{ }^{*} \mathrm{NPF}\right)$ & -0.130162 & 0.240192 & -0.541910 & 0.5891 \\
\hline $\mathrm{D}\left(\mathrm{FIR}{ }^{\star} \mathrm{NPF}\right)$ & -0.179099 & 0.071666 & -2.499062 & 0.0142 \\
\hline $\mathrm{D}\left(\mathrm{NOM}^{*} \mathrm{NPF}\right)$ & 3.966542 & 0.828953 & 4.785005 & 0.0000 \\
\hline ECT(-1) & -0.533200 & 0.088835 & -6.002161 & 0.0000 \\
\hline Adj. R-Squared & \multicolumn{4}{|c|}{0.454263} \\
\hline F-Statistik & \multicolumn{4}{|c|}{9.823268} \\
\hline Prob. F-Statistik & \multicolumn{4}{|c|}{0.0000} \\
\hline
\end{tabular}

Source: Eview 10 Software Processing Results

Berdasarkan hasil estimasi pada Tabel 4.7, maka dapat dituliskan persamaan model jangka pendek dalam penelitian sebagai berikut:

$\mathrm{ROE}=0.029420+0.400103 \mathrm{D}(\mathrm{FDR})+0.647968 \mathrm{D}(\mathrm{CASA})+0.963511(\mathrm{FIR})-$ $13.67546 \mathrm{D}(\mathrm{NOM})+5.050030 \mathrm{D}(\mathrm{NPF})-0.021727 \mathrm{D}\left(\mathrm{FDR}{ }^{*} \mathrm{NPF}\right)$ 


\section{$0.130162 \mathrm{D}\left(\mathrm{CASA}^{*} \mathrm{NPF}\right)-0.179099 \mathrm{D}\left(\mathrm{FIR}^{*} \mathrm{NPF}\right)+3.966542 \mathrm{D}\left(\mathrm{NOM}^{*} \mathrm{NPF}\right)-$

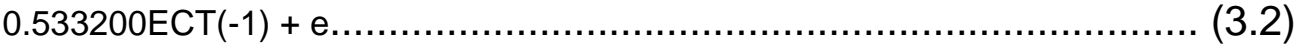

The results of the ECM model in table 4.8, show the coefficient of ECT is -0.533200 with prob. t-stat of $0.0000<0.05(\alpha)$. This shows that the ECM model in this study can be used to analyze the short-term effect.

In equation 3.2, it is found that in the short term FDR, CASA, and NPF have a positive and insignificant effect on prob. $t$-stat is greater $(>)$ 0.05. While NOM and FIR have a significant effect on the prob value. $t$-stat is smaller $(<) 0.05$ and each coefficient value is negative and positive. FDR and CASA moderated by NPF in the short term have a negative and insignificant effect. However, NOM and FIR moderated by NPF have a significant effect on the prob value. t-stat is smaller $(<) 0.05$ where NOM has a positive effect and FIR has a negative effect.

The ability of the independent variable in explaining the dependent variable in the short-term estimation is 0.454263 or 45 percent, the remaining 55 percent is influenced by other variables that are not included in the model or errors. The effect of independent variables on ROE together has a significant effect. This can be seen from the estimation results of prob. f-stat of $0.0000<0.05(\alpha)$.

\subsection{Discussion}

\subsubsection{Effect of FDR on Shareholder Ratio (ROE)}

Based on the results of this study, it is known that the ratio of financing distribution to third party funds (FDR) both long-term model and short-term model has a positive effect on the shareholder welfare ratio (ROE). Based on the long-term model, FDR has a significant effect on ROE, because the higher the FDR, the better the performance of Islamic banks which is represented by the ROE ratio. The high FDR ratio is caused by the distribution of financing to the public which is the core business of Islamic banks as intermediary institutions. Meanwhile, based on research, the short-term FDR model has no significant effect on ROE. In addition, the good intermediary function of Islamic banks is indicated by the average financing distribution ratio (FDR) during 2020 (January-December) of Islamic banks is $85.28 \%$. This ratio shows that Islamic banks have the ability to channel the funds they have collected because to the provisions of SE BI regulation No.15/41/DKMP, regarding the Calculation of Secondary Statutory Reserves and Statutory Reserves based on the Financing to Deposit Ratio in Rupiah, the minimum ratio is distribution of financing to third party funds (FDR) is $78 \%$.

\subsubsection{Effect of CASA on Shareholder Ratio (ROE)}

Based on the results of long-term and short-term research, the low-cost funds ratio (CASA) has no significant effect on the shareholder welfare ratio (ROE). Therefore, the CASA ratio does not have a direct effect on improving performance, but depends on the product innovation offered to the public. In Sulaiman's research entitled "Marketing Strategy for Wadi'ah Savings Products at Islamic Banks' ', the results of this study can be concluded that the marketing strategies carried out include prioritizing customers on CASA with low-cost funds, redesigning the benefits of products and technology through various channels. In Jamitko's research a marketing strategy to develop and attract public interest in using one of the superior products of Islamic banks by implementing a 4P marketing mix strategy consisting of product, price, place, and promotion. By innovating low-cost fund products and creating programs that can attract public attention, it can be an effort to improve the performance of Islamic banks.

\subsubsection{Effect of NOM on Shareholder Ratio (ROE)}

The results of the study for the NOM ratio, both the long-term model and the shortterm model, showed a significant effect on the shareholder welfare ratio (ROE). Net Operating Margin (NOM) is a ratio that measures the ability of productive assets to generate net income. The greater the NOM ratio, the Islamic bank is efficient in managing its productive assets so that profitability will increase. This is evidenced in research conducted by Vita Tristiningtyas (2013) showing that Net Operating Margin (NOM) has a positive effect on profitability. Islamic banks are committed to channeling productive assets to segments to sharia principles and 
providing benefits to employees, stakeholders and shareholders (shareholders).

\subsubsection{Effect of FIR on Shareholder Ratio (ROE)}

Based on the results of short-term research, the FIR ratio has a positive and significant effect on the shareholder welfare ratio (ROE). Meanwhile, based on the long-term model research, the FIR ratio has no significant effect on ROE. Fee-based income in the short term has an effect on bank income, this is in line with the results of previous studies showing that fee-based income has a significant effect on profitability. The increase in fee-based income is in line with the development of technology and information in the banking world. Therefore, Islamic banks must focus more on the development of office networks, distribution channels and product innovations to improve financial performance.

\subsubsection{Effect of NPF on Shareholder Ratio (ROE)}

Based on the results of long-term and short-term research, the financing quality ratio (NPF) has no significant effect on the shareholder welfare ratio (ROE). The results of this study indicate that NPF does not have a direct effect on ROE, this is different from previous studies conducted where NPF has a negative and significant effect on bank performance. The quality of financing distribution (NPF) for Islamic banks is an important financial indicator for Islamic banks in maintaining the bank's reputation. This is because, if the NPF of a bank is very high, it indicates that the bank has a high potential risk so that it has an impact on the decline in the reputation of the Islamic bank in the community .

\subsubsection{Effect of FDR on Shareholder Ratio (ROE) with NPF as Moderating Variable}

Based on the results of the long-term model research that NPF moderates the effect of FDR on the shareholder welfare ratio (ROE), it has a negative and significant effect. NPF as a moderating variable strengthens the effect of FDR on ROE, so that the better the FDR is, the better the NPF will have implications for increasing ROE. the distribution of financing as one of the main activities of Islamic banks will have implications for the profits of Islamic banks. Therefore, based on the results of this study, financial performance strengthens the effect of FDR on ROE. On the other hand, based on short-term model research, the NPF moderating the effect of FDR on ROE has no significant effect.

\subsubsection{Effect of FDR on Shareholder Ratio (ROE) with NPF as Moderating Variable}

Based on the results of the study that NPF moderates the effect of CASA on the shareholder welfare ratio (ROE), both the long-term model and the short-term model have no significant effect. One of the efforts made by Islamic banks in collecting cheap funds from the public is to innovate products and improve service quality. With product innovation and supported by an extensive network, Islamic banks can compete with conventional banks in an effort to grab low-cost funds, which aims to not only increase profit sharing costs but also increase revenue. Islamic banking is required to obtain maximum Third Party Funds (DPK) in carrying out business activities. Third party funds are the bank's main funds to distribute financing. DPK consists of lowcost sources of funds and expensive sources of funds, where Islamic banking third party funds are dominated by expensive funds, namely deposits in the range of $48.73 \%$ (as of December 2020) so that the cost of funds borne by Islamic banking is relatively high. explains that the cost of funds is the cost that must be paid by the bank for each fund it collects. In Badina's research (2017:103), the cost of funds (CoF) is one of the factors in determining pricing, thus affecting the profits obtained by Islamic banking. Therefore, Islamic banking needs to reduce the cost of funds to the lowest position in order to obtain optimal profits through an increase in Current Account Saving Accounts (CASA).

\subsubsection{Effect of NOM on Shareholder Ratio (ROE) with NPF as Moderating Variable}

Based on the results of the long-term and short-term model research that NPF moderates the effect of NOM on the shareholder welfare ratio (ROE) it has a negative and significant effect. The net operating margin itself is a ratio that is closely related to the bank's ability to manage productive assets so that it can generate a margin or net profit sharing 11. This is also in line with previous research conducted stated that the Net Operating Margin (NOM) variable has a positive effect on profitability. The results of another study conducted by Rifai and Suyono (2019) stated 
that the higher the Net Operating Margin (NOM) ratio, the higher the operating income obtained from assets. productive banks managed to increase the profitability of Islamic banks.

\subsubsection{Effect of FIR on Shareholder Ratio (ROE) with NPF as Moderating Variable}

Based on the results of the short-term model research that NPF moderates the effect of FIR on the shareholder welfare ratio (ROE) it has a negative and significant effect. Meanwhile, based on the long-term model research, NPF moderates the effect of FIR on ROE without a significant effect. In addition to carrying out several functions and roles as intermediary institutions, banks also carry out other bank services. In providing its services, banks are required to provide various conveniences in conducting financial transactions with various forms of bank products by developing banking technology for the community. Fee based income is income from fees, fees or commissions obtained by the bank which is not interest income. Meanwhile, Feebased income is the profit obtained from transactions provided in other bank services. explained that the principle of service/fee in Islamic banks includes all non-financing services provided by banks. Products based on this principle include bank guarantees, clearing, collections, services/transfers, and others.

\subsubsection{Effect of All Variables (FDR, CASA, NOM, FIR and NPF) on Shareholder Ratio (ROE)} the results of the study in table 4.6 where the variables FDR, CASA, NOM, FIR and NPF as well as FDR moderated by NPF, CASA moderated by NPF, NOM moderated by NPF and FIR moderated by NPF simultaneously affect the shareholder welfare ratio (ROE). The influence is $79.81 \%$, while the remaining $20.19 \%$ is influenced by other factors.

Furthermore, the results of the study are based on table 3.4 where the variables FDR, CASA, NOM, FIR and NPF as well as FDR moderated by NPF, CASA moderated by NPF, NOM moderated by NPF and FIR moderated by NPF simultaneously affect the shareholder welfare ratio $(\mathrm{ROE})$. The influence is $45.42 \%$ while the remaining $54.58 \%$ is influenced by other factors.

\subsection{Implementation of Research Results}

Al-Quran as a guide and guide for Muslims regulates all dimensions of life, including the banking world. However, in order to maximize the teachings of sharia in a kaffah manner, the values contained in the Qur'an must be able to be derived at a practical level. One of the efforts and steps in order to find a future banking formula, Al-Quran and Hadith have a conception in the operational activities of Islamic Banks. This is done to form a mental attitude or character that is described in the pattern of thinking, way of speaking, and ethical behavior, as an expression of the soul of a human being who believes and fears Allah SWT so that Muslims are able to become superior people (khayr ummah).

From the application of Qur'anic values, it is expected that Islamic banking has a commitment to realizing justice and the welfare of human life (al-falah) in general. Therefore, the existence of Islamic banks is the implementation of sharia law which is sourced from the Qur'an, hadith and other sources of Islamic law. Furthermore, Islamic banks run their business based on Islamic law, so the main goal of Islamic banks is to provide justice for the entire Ummah and also so that Muslims can carry out their religious teachings in a kaffah (total) manner. The existence of Islamic banks must contribute to improving the welfare of the ummah.

Islamic banks that carry out their business activities based on sharia principles must have good performance, this is in line with the implementation of the Tawhidi String Relation concept. In addition, Islamic banks also in carrying out their activities have the mandate of all stakeholders as responsibilities in managing the business, especially managing people's funds. One of the expectations of Islamic banks is the trust of shareholders to manage the paid-in capital provided as an investment for business expansion in return for a certain percentage return on the ROE ratio. Therefore, Islamic banks must be able to provide maximum contribution with the best performance for the welfare of shareholders. This is indicated by the ROE variable being influenced by independent variables, namely the financing distribution ratio (FDR), muarah fund ratio (CASA), NOM ratio, fee-based ratio (FIR) and financing quality ratio (NPF). In addition, to maintain financial performance and shareholder expectations, Islamic banks must do the following: 
- The intermediation function carried out by Islamic banks is very important because this is the core of banking business activities so that good management will certainly bring profit. In practice, banks channel the funds collected through financing products that are in accordance with the needs and desires of the community in accordance with fair contracts such as musyrakah and mudharabah contracts;

- Raising low-cost funds has become the focus of Islamic banking in making efficiency of profitsharing costs to depositors, thereby increasing optimum income;

- The ability of Islamic banks to manage their earning assets and have a commitment to distribute productive assets with competitive yields and provide benefits to all parties;

- Improving transaction banking through an e-channel network that is spread out, utilizing technology and offering competitive banking products, services and services;

- Maintaining the reputation of Islamic banks through the distribution of quality financing so that people feel safe to place their funds in Islamic banks.

Islamic banks in disbursing financing are also influenced by the various products they have, including profit sharing, buying and selling and leasing and even have unique products that are not owned by conventional banks, including mortgage financing and gold installments. This more varied and innovative Islamic bank financing product can boost performance, especially the ROE ratio. In calculating ROE, Islamic banks have also taken into account the company's zakat issued in order to provide welfare for the people.

In its development, several state-owned Islamic banks were merged and merged, so that the superior products in each Islamic bank complemented each other and added diversity. This condition is an advantage for Islamic banks in competing with conventional banks to improve the welfare of shareholders while also becoming more efficient Islamic banks.

\section{Conclusion}

\subsection{Research Conclusion}

This study was conducted to obtain empirical evidence in order to answer questions about the factors that affect the financial performance of Islamic banks that have an impact on the welfare of shareholders. In accordance with the results and discussion in this study, the ROE ratio can be used as a variable to measure the welfare of shareholders and the performance of Islamic banks. The welfare of shareholders here is the performance achieved by Islamic banks in obtaining operating profit which is represented by the achievement of the ROE ratio. The higher the ROE of the Islamic bank, the higher the operating profit obtained so that it can meet the expectations of shareholders, both shareholders and stakeholders as a whole.

Based on the research results from the long-term model, FDR has a positive and significant effect on the ROE ratio, the NOM ratio has a negative and significant effect on the ROE ratio. While the variables of the CASA ratio, FIR ratio and NPF ratio have no effect on the ROE ratio. Furthermore, the moderating variable NPF strengthens the relationship of all direct and significant variables to the shareholder welfare ratio (ROE), namely NPF moderates the negative and significant effect of FDR on the ROE ratio, NPF moderates the positive and significant effect of the NOM ratio on the ROE ratio. Furthermore, other variables NPF moderating CASA and FIR have no effect on the ROE ratio. While the results of short-term research with ECM, FIR has a positive and significant effect on the ROE ratio, the NOM ratio has a negative and significant effect on the ROE ratio. While the variables of FDR ratio, CASA ratio and NPF ratio have no effect on the ROE ratio. Furthermore, the moderating variable NPF strengthens the relationship of all direct and significant variables to the shareholder welfare ratio (ROE), namely NPF moderates the negative and significant effect of FIR on the ROE ratio, NPF moderates the positive and significant effect of the NOM ratio on the ROE ratio. While other variables NPF moderating FDR and CASA have no effect on the ROE ratio.

Furthermore, in more detail the variables that affect the shareholder welfare ratio (ROE) used in this study are as follows:

1. In the long-term model, the ratio of financing distribution represented by the variable financing to deposit ratio (FDR) has a positive and significant effect on the shareholder welfare ratio (ROE). Meanwhile, in the short-term model, FDR has no effect on the shareholder welfare ratio (ROE). Based on this, it shows that in the distribution of financing in Islamic banks, it must be sustainable and distributed to retail segments that are healthy and have competitive yields. In this condition, it is expected that Islamic banks should be able to increase their FDR ratio 
(range of $85 \%-90 \%$ ) in order to compete with conventional banks so as to be able to maintain good financial performance. The provision of sustainable financing in addition to having an impact on increasing income also encourages growth in the real sector. Meanwhile, in the short term FDR does not have a direct effect on financial performance because the provision of financing has not contributed to the maximum income. Islamic banks as intermediary institutions have the main function of mobilizing funds collected from the community and channeling them back to the community to drive the national economy. The better the intermediation function of Islamic banks, in the long term it will improve financial performance and welfare;

2. The low-cost funds ratio (CASA) has no effect on the shareholder welfare ratio (ROE), both long-term and short-term research models. Based on this, it shows that the collection of lowcost funds in Islamic banks is still a challenge, both in the form of product innovation offered and the quality of services provided to the public. Islamic banks must be able to compete with conventional banks to collect cheap funds sourced from demand deposits and savings in order to increase bank income and efficiency in profit sharing costs issued by banks to depositors. Besides that, cheap fund products offered by Islamic banks must also be able to compete and be competitive with conventional banks, for example mabrur savings and qurban savings which only exist in Islamic banks;

3. The Net Operating Margin (NOM) ratio in both the long-term and short-term research models has a negative and significant effect on the shareholder welfare ratio (ROE). Therefore, efforts to manage productive assets in a professional manner will provide a sense of trust both from shareholders who have invested capital in banks for expansion, as well as trust from all stakeholders. This good management of productive assets will be seen from the performance generated by Islamic banks in obtaining operating profit in this case the optimal ROE ratio;

4. In the short-term model the ratio of fee-based income to operating income which is represented by the FIR ratio has a positive and significant effect on the shareholder welfare ratio (ROE). Meanwhile, in the long-term model, FIR has no effect on the shareholder welfare ratio (ROE). Based on this, it shows that in the short term, fee-based income has a direct impact on bank income. This condition requires Islamic banks to be able to adapt quickly and innovate on feebased products offered, so that in the short term banks can compete with conventional banks. Meanwhile, in the long term, the fee-based ratio does not have a direct effect because the ratio in this study is based on annual data. Fee-based is an important source of income for Islamic banks apart from providing financing. Islamic banks are required to be able to compete with conventional banks through innovation and quality services in accordance with customer and community expectations. In addition, technological and digital-based product innovations also encourage Islamic banks to increase revenue through fee-based transaction banking;

5. The ratio of the quality of non-performing financing represented by the variable non-performing financing (NPF) has no effect on the shareholder welfare ratio (ROE), both long-term and short-term research models. Based on this, it shows that in managing non-performing financing in Islamic banks, banks have made a cash provision for debtor collectibility, so it is hoped that banks will not experience income problems if there is a customer default. The quality of financing as one of the main financial indicators in the banking industry is an important factor to assess that the bank is able to manage its financing well. Therefore, the lower the quality of non-performing financing, the larger the loss reserves formed by Islamic banks to cover financing installments that customers cannot afford to pay;

6. In the long-term model research, non-performing financing (NPF) as a moderating variable strengthens the effect of FDR on the shareholder welfare ratio (ROE). Meanwhile, in the study of the short-term NPF model, FDR moderation has no effect on the shareholder welfare ratio (ROE). The activities of Islamic banks by channeling financing properly will have an impact on increasing profits so that they will contribute to increasing ROE. Based on this, the NPF variable will indirectly strengthen the influence of FDR on ROE. This is indicated by the results of a long-term model study where the effect of FDR on ROE moderated by NPF has a negative and significant effect;

7. Non-performing financing (NPF) as a moderating variable of CASA has no effect on the shareholder welfare ratio $(\mathrm{ROE})$, both long-term and short-term research models. The current strategy of Islamic banks in raising public funds is not only to increase bank assets, but also to improve the structure of the funding owned by banks. Therefore, the presence of Islamic 
bank offices throughout Indonesia is one of the efforts to raise low-cost funds through savings. In addition, it is also necessary to socialize Islamic banks to the public on how to make it easier for their customers to access Islamic banking facilities and services.

8. Non-performing financing (NPF) as a moderating variable strengthens the effect of NOM on the shareholder welfare ratio (ROE). Therefore, the activities of Islamic banks by channeling productive assets properly will have an impact on increasing profits so that they will contribute to increasing ROE. Based on this, the NPF variable will indirectly strengthen the influence of NOM on ROE. This is indicated by the results of this study where the effect of NOM on ROE moderated by NPF has a positive and significant effect on both long-term and short-term research models;

9. In the short-term model research, non-performing financing (NPF) as a moderating variable strengthens the effect of FIR on the shareholder welfare ratio (ROE). Meanwhile, in the longterm NPF model research, FIR moderation has no effect on the shareholder welfare ratio (ROE). Islamic banks continue to innovate in developing fintech-based products in order to compete with conventional banks in providing services and services to the entire community in an effort to increase bank income.

\subsection{Theoretical Implications}

The findings in this study broadly strengthen the concepts and theories related to performance measurement of Islamic banks. The novelties revealed in detail from the results of this study are as follows:

1. The welfare of shareholders in this case the performance of Islamic banks can be measured by the ROE ratio approach, so that ROE can be used as an indicator to measure the welfare of shareholders in this case the performance of Islamic banks in addition to other financial ratios;

2. The variables that significantly affect the shareholder welfare ratio $(R O E)$ are the financing distribution ratio (FDR), the productive asset distribution ratio (NOM) and the fee-based income ratio (FIR);

3. Islamic financial performance, which is represented by a good ROE ratio, means meeting the expectations and milestones expected by shareholders in managing the capital investment that has been placed, so that the ROE ratio becomes a measure of the success of Islamic bank management in managing Islamic banks in a healthy and sustainable manner.

\subsection{Managerial Implications}

This research produces useful findings for Islamic bank management and Islamic banking practitioners as well as all relevant stakeholders, including:

1. In managing Islamic banks whose aim is not only to provide profits and welfare for shareholders (shareholders) but also to provide welfare for all stakeholders, Islamic banks in their operations must maintain healthy and sustainable financial indicators. The financial indicators that can significantly influence the Return on Equity (ROE) in this study are the management of the ratio of financing to third party funds (FDR), the ratio of productive asset management, asset quality and efficiency (NOM) and fee-based income. income (FIR);

2. Islamic banks have a competitive advantage over conventional banks, where Islamic banks in running their business in addition to applying the principles of fairness, balance and benefit, they also carry out the mandate of shareholders, regulators and the ummah (stakeholders), so that the resulting financial ratios in this case ROE ratio already reflects the welfare that will be obtained from shareholders in accordance with the objectives of Islamic banks is maqashid sharia;

3. Islamic banks must be able to carry out their intermediation function properly, especially in distributing financing, especially for products that are different from conventional banks such as gold pawn financing and gold installments. In addition, Islamic banks focus on channeling financing to the retail sector, such as Islamic home financing and sharia partners. Optimal distribution of financing (financing to deposit ratio) will have implications for increasing the shareholder welfare ratio (ROE);

4. Islamic banks must be able to compete with conventional banks in raising low-cost funds (CASA). Therefore, Islamic banks need to carry out a network structuring strategy, both 
opening networks and distribution channels, funding product innovations, service quality and product knowledge for sales or marketing personnel;

5. Islamic banks, most of which are managing third party funds and distributing productive assets, must be managed professionally, soundly and prudently, so that the quality of financing is maintained. In raising public funds, the focus is on low-cost funds to maintain cost efficiency and the distribution of financing is focused on the retail segment. The Net Operating Margin (NOM) ratio, in addition to reflecting optimal management of productive assets, also optimizes fee-based income with a number of office networks spread throughout remote areas and supported by adequate technology. Controlling overhead costs and maintaining the quality of financing represented by PPAP or CKPN costs are also included in improving the performance of the NOM ratio which has an impact on increasing the performance of Islamic banks;

6. Increasing the income of Islamic banks on a fee-based basis as the second core of the bank's mine business, namely financing. Furthermore, in the future Beyond Banks will focus on income derived from transaction banking by relying on digital platforms. Islamic banks must be able to compete with conventional banks in offering digital and fintech-based products and services that have an impact on increasing the performance of Islamic banks;

7. The quality of Islamic bank financing needs to be managed properly to maintain the reputation of Islamic banks in the community. Although the results of this study state that the quality of non-performing financing does not directly affect the welfare of shareholders (ROE), in a healthy and prudent Islamic bank management, banks must make cash provision reserves in anticipation of a default customer. Therefore, the management of Islamic banks must be able to properly manage the distribution of financing in accordance with prudential principles.

\subsection{Research Suggestions}

The performance of Islamic banks in their operations in addition to paying attention to sharia aspects also pays attention to aspects of benefit. In its development, Islamic banks still need support from shareholders, both in the form of capital deposits, technology, as well as collaboration between human resources. Therefore, most of the BUS in Indonesia are still shareholdings of conventional banks. Therefore, Islamic banks in managing performance have milestones that are set by shareholders as an expectation of Islamic banks and are carried out responsibly and professionally. To increase the sense of trust in shareholders, Islamic banks strive to continuously improve performance through financial ratio indicators, one of which is the $\mathrm{ROE}$ ratio. Furthermore, to improve performance in these aspects, Islamic banks must be able to do the following:

1. Optimizing the intermediation function by maintaining the FDR ratio above the provisions of Islamic banks, which is $80 \%$. For Islamic banks that are productive, the FDR ranges from $85 \%$ to $90 \%$;

2. Increase low-cost fund collection (CASA), especially savings through socialization and education to the public and offering products that are characteristic of Islamic banks, including umrah savings, hajj savings, qurban savings as well as product innovation and improving service quality;

3. Improve professional and prudent management of productive assets by increasing Net Operating Margin (NOM) for targeted customer segments with competitive yields, focusing on low-cost funds, transaction banking, financing quality management and cost control in order to achieve prosperity (benefit);

4. Increase fee-based income-based sharia bank income by innovating products, including the development of digital platforms through mobile banking applications with features including purchases, payments, transfers, online gold, Ziswaf, QRIS and so on. Besides that, conducting network arrangement, distribution channel and increasing competence through product knowledge for sales and marketing;

5. Control the expenditure of operational costs and manage loss reserves in this case PPAP and CKPN costs by maintaining the quality of financing (NPF) from Islamic banks in order to maintain the reputation of Islamic banks in the eyes of shareholders and stakeholders.

6. For further research, financial variables can be added such as aspects of capital, and aspects of sustainable finance in order to improve the performance and welfare of stakeholders. 


\section{References}

[1] Agustin, F., Aini, Q., Khoirunisa, A., \& Nabila, E. A. (2020). Utilization of Blockchain Technology for Management E-Certificate Open Journal System. Aptisi Transactions on Management (ATM), 4(2), 133-138.

[2] Hendriyati, P., Agustin, F., Rahardja, U., \& Ramadhan, T. (2022). Management Information Systems on Integrated Student and Lecturer Data. APTISI Transactions on Management (ATM), 6(1), 1-9.

[3] Rahardja, U., Lutfiani, N., \& Amelia, S. (2019). Creative Content Marketing In Scientific Publication Management In Industrial Era 4.0. Aptisi Transactions on Management (ATM), 3(2), 168-177.

[4] Aini, Q., Alwiyah, A., \& Putri, D. M. (2019). Effectiveness of Installment Payment Management Using Recurring Scheduling to Cashier Performance. Aptisi Transactions on Management (ATM), 3(1), 13-21.

[5] Aini, Q., Handayani, I., \& Lestari, F. H. N. (2020). Utilization Of Scientific Publication Media To Improve The Quality Of Scientific Work. Aptisi Transactions on Management (ATM), 4(1), 1-12.

[6] Maharani, A., Aninda, S., \& Millah, S. (2021). Pembuatan Kartu Ujian Online Sebagai Pengabdian Perguruan Tinggi. ADI Pengabdian Kepada Masyarakat, 1(2), 8-14.

[7] Yaniaja, A. K., Wahyudrajat, H., \& Devana, V. T. (2020). Pengenalan Model Gamifikasi ke dalam E-Learning Pada Perguruan Tinggi. ADI Pengabdian Kepada Masyarakat, 1(1), $22-$ 30.

[8] Abdullah, D., Rahardja, U., \& Oganda, F. P. (2021). Covid-19: Decentralized Food Supply Chain Management. Syst. Rev. Pharm, 12(3), 142-152.

[9] Kosasi, S. (2020). Karakteristik Blockchain Teknologi Dalam Pengembangan Edukasi. ADI Bisnis Digit. Interdisiplin J, 1(1), 87-94.

[10] Pambudi, A., Widayanti, R., \& Edastama, P. (2021). Trust and Acceptance of E-Banking Technology Effect of Mediation on Customer Relationship Management Performance. ADI Journal on Recent Innovation, 3(1), 87-96.

[11] Santoso, R. E., Oganda, F. P., Harahap, E. P., \& Permadi, N. I. (2021). Pemanfaatan Penggunaan Hyperlocal Marketing bagi Startup Bidang Kuliner di Tangerang. ADI Bisnis Digital Interdisiplin Jurnal, 2(2), 60-65.

[13] Wahyuningsih, T., Oganda, F. P., \& Anggraeni, M. (2021). Design and Implementation of Digital Education Resources Blockchain-Based Authentication System. Blockchain Frontier Technology, 1(01), 74-86.

[14] Rahardja, U., Lutfiani, N., Aini, Q., \& Annisa, I. Y. (2021). The Potential Utilization of Blockchain Technology. Blockhain Front. Technol, 1(01), 57-67.

[15] Sunarya, P. A., \& Lutfiani, N. (2020). Analisis Sistem Sertifikasi Profesi Untuk Pengembangan Kompetensi Mahasiswa. ADI Bisnis Digital Interdisiplin Jurnal, 1 (1 Juni), 70-77.

[16] Rahardja, U., Handayani, I., Lutfiani, N., \& Oganda, F. P. (2020). An Interactive Content Media on Information System iLearning+. IJCCS (Indonesian Journal of Computing and Cybernetics Systems), 14(1), 57-68.

[17] Rahardja, U., Lutfiani, N., \& Juniar, H. L. (2019). Scientific Publication Management Transformation In Disruption Era. Aptisi Transactions on Management (ATM), 3(2), 109118.

[18] Hardi, E. A. (2019). Fatwa DSN MUI dan Perkembangan Produk Perbankan Syariah di Indonesia. An-Nisbah: Jurnal Ekonomi Syariah, 6(1), 82-105.

[19] Landali, A., \& Yusuf, N. (2020). Metafora DOA sebagai makna laba dalam perspektif Islam. Imanensi: Jurnal Ekonomi, Manajemen, dan Akuntansi Islam, 5(2), 116-125.

[20] Yaniaja, A. K., Wahyudrajat, H., \& Devana, V. T. (2020). Pengenalan Model Gamifikasi ke dalam E-Learning Pada Perguruan Tinggi. ADI Pengabdian Kepada Masyarakat, 1(1), 2230.

[21] Idrus, A. (2018). Pengaruh Faktor Internal dan Eksternal Terhadap Return On Equity (ROE). Misykat Al-Anwar, 29(2), 257186.

[22] Irhamsyah, A. (2010). Analisis pengaruh Capital Adequacy Ratio (CAR), biaya operasional 
terhadap pendapatan operasional (BOPO), dan Financing To Deposit Ratio (FDR) terhadap Return on Equity (ROE). lamsyah, H. (2012). Perkembangan dan Prospek Perbankan Syariah Indonesia: Tantangan Dalam Menyongsong MEA 2015. Milad Ke-8 Ikatan Ahli Ekonomi Islam (IAEI), (April 2012), 1-8.

[23] Ihwanudin, N., Maulida, S., Ilham Akbar Fatriansyah, A., Sari Rahayu, S., Nugroho, L., Widyastuti, S., ... Arzhi Jiwantara, F. (2020). Pengantar Perbankan Syariah (Konsep, Regulasi \& Praktis). Widya Bhakti Persada Bandung. Retrieved from www.penerbitwidina.com

[24] Jusmansyah, M., \& Sriyanto, A. (2010). Analisis Pengaruh CAR, BOPO dan ROA Terhadap Non Performance Loan. Jurnal Akuntansi Dan Keuangan, 2(1), 46-65.

[25] Rakhmansyah, M., Rahardja, U., Santoso, N. P. L., Khoirunisa, A., \& Faturahman, A. (2021). Smart Digital Signature berbasis Blockchain pada Pendidikan Tinggi menggunakan Metode SWOT. ADI Bisnis Digital Interdisiplin Jurnal, 2(1), 39-47.

[26] Az-Zahra, R. S. A., Jaelani, A., \& Nursi, M. (2021). Pengaruh Pengendalian Internal Dan Integritas Karyawan Terhadap Pencegahan Kecurangan (Fraud) Pada PT. Bank KEB Hana Indonesia Wilayah Jakarta. ADI Bisnis Digital Interdisiplin Jurnal, 2(2), 38-44.

[27] Harriguna, T., \& Wahyuningsih, T. (2021). Kemajuan Teknologi Modern untuk Kemanusiaan dan Memastikan Desain dengan Memanfaatkan Sumber Tradisional. ADI Bisnis Digital Interdisiplin Jurnal, 2(1), 65-78.

[28] Santoso, R. E., Oganda, F. P., Harahap, E. P., \& Permadi, N. I. (2021). Pemanfaatan Penggunaan Hyperlocal Marketing bagi Startup Bidang Kuliner di Tangerang. ADI Bisnis Digital Interdisiplin Jurnal, 2(2), 60-65.

[29] Prawiyogi, A. G., Anwar, A. S., Yusup, M., Lutfiani, N., \& Ramadhan, T. (2021). Pengembangan Program Studi Bisnis digital bagi pengusaha dengan perangkat lunak lean. ADI Bisnis Digital Interdisiplin Jurnal, 2(2), 52-59.

[30] Agustin, F., Oganda, F. P., Lutfiani, N., \& Harahap, E. P. (2020). Manajemen Pembelajaran Daring Menggunakan Education Smart Courses. Technomedia Journal, 5(1 Agustus), 4053. 